\title{
AZT on telomerase activity and cell proliferation in HS 839.T melanoma cells ${ }^{1}$
}

\author{
AZT na atividade da telomerase e na proliferação de células de melanoma HS 839.T
}

\author{
Celestino Prospero de Souza SobrinhoI, Alfredo Gragnani" ${ }^{\mathrm{II}}$, Ivan Dunshee Abranches Oliveira Santos ${ }^{\mathrm{III}}$, Andrea Fernandes \\ Oliveira $^{\mathrm{IV}}$, Monica Vanucci Nunes Lipay ${ }^{\mathrm{v}}$, Lydia Masako Ferreira ${ }^{\mathrm{VI}}$ \\ IFellow Master degree, Plastic Surgery Division, Department of Surgery, EPM-UNIFESP, Sao Paulo-SP, Brazil. Main author. Conception, design, \\ intellectual and scientific content of the study, technical procedures, acquisition and interpretation of data, manuscript writing. \\ "IPhD, Associate Professor, Plastic Surgery Division, Department of Surgery, EPM-UNIFESP, Sao Paulo, Brazil. Conception and design of the study, \\ critical revision. \\ IIPhD, Head, Plastic Surgery Division, Department of Surgery, EPM-UNIFESP, Sao Paulo-SP, Brazil. Interpretation of data, critical revision. \\ ${ }^{\mathrm{IV}}$ Fellow Master degree, Postgraduate Program in Plastic Surgery, EPM-UNIFESP, Sao Paulo-SP, Brazil. Critical revision. \\ ${ }^{v} \mathrm{PhD}$, Associate Professor, Division of Endocrinology, Department of Medicine, EPM-UNIFESP, Sao Paulo-SP, Brazil. Interpretation of data, critical \\ revision. \\ VIPhD, Full Professor, Chairwoman, Plastic Surgery Division, Department of Surgery, EPM-UNIFESP, Sao Paulo-SP, Brazil. Critical revision.
}

\author{
ABSTRACT \\ PURPOSE: To evaluate telomerase activity and proliferation of HS839.T melanoma cells, subjected to the action of AZT. \\ METHODS: Cells were grown in triplicate, AZT at different concentrations: 50, 100 and $200 \mu \mathrm{M}$, was added and left for 24 and 48 \\ hours, and its effects were compared with the control group. Telomerase activity was detected by PCR and cell proliferation was \\ evaluated by MTT.
}

RESULTS: After 24 hours, there was no inhibition of cell proliferation or telomerase activity when compared to the control group. After 48 hours, there was a momentary decrease, suggesting that the cell lines used in this study are sensitive to AZT, but quickly recover both the enzyme activity and cell proliferation.

CONCLUSION: The action of AZT on the melanoma cells studied, at the concentrations and times tested, did not inhibit telomerase activity nor affect cell proliferation.

Key words: Telomerase. Melanoma. Zidovudine. Cell Proliferation. In Vitro.

\section{RESUMO}

OBJETIVO: Avaliar a atividade da telomerase e da proliferação de células de melanoma HS839.T submetidas à ação do AZT.

MÉTODOS: As células foram cultivadas, em triplicata, com diferentes concentrações de AZT: 50, 100 e $200 \mu \mathrm{M}$, por 24h e 48h, seus efeitos comparados com o grupo controle. A atividade da telomerase foi detectada por PCR e a proliferação celular avaliada por MTT. RESULTADOS: No tempo de 24 horas, não houve inibição da proliferação celular e da atividade da telomerase em comparação com o grupo controle. No período de 48 horas, houve uma diminuição momentânea, sugerindo que as células das linhagens utilizadas neste estudo são sensíveis ao AZT, mas que recuperam a atividade enzimática e proliferativa.

CONCLUSÃO: Nas células de melanoma HS839.T estudadas e nas concentrações e tempos propostos, a ação do AZT não inibiu a atividade da telomerase e não afetou a proliferação celular.

Descritores: Telomerase. Melanoma. Zidovudina. Proliferação de Células. In Vitro. 


\section{Introduction}

Melanoma results from the uncontrolled proliferation of melanoblasts, of unknown etiology, and is one of the tumour with poorest prognosis. Several factors contribute to its arising, such as a genetic predisposition, exposure to sunlight, physical traumas to pre-existent nevi and immunodeficiencies. Melanoma accounts for 3 to $4 \%$ of all malignant skin tumour ${ }^{1-4}$. Reports from various parts of the world have demonstrated an increase in its incidence and mortality rates ${ }^{5,6}$.

Cancer cells present alterations in their nuclei, which usually occur in a single somatic cell that continues to divide until it forms a tumor. Its growth is fostered, among others, by angiogenic factors secreted by these cells, affecting even the maintenance of the DNA telomere size ${ }^{7-9}$.

Telomeres are specialized structures located at the ends of eukaryotic chromosomes, constituted of complex nucleoproteins and essential for the stability of the genome $e^{10,11}$. Any telomere dysfunction contributes to reduce cell viability, altering the differentiation process ${ }^{12,13}$.

The enzyme responsible for telomere synthesis is known as telomerase. It protects the ends of the DNA molecule against enzymatic degradation, preventing the occurrence of extremity fusions and warranting a correct duplication of the terminal regions of chromosomes, which may be necessary for the indefinite proliferation of human cells ${ }^{11,14}$.

Telomerase activity is absent in the majority of human somatic cells but present in immortalized cell lines, stem and germ cells and in approximately $90 \%$ of human cancers ${ }^{15}$. There are studies suggesting that the progression of malignant diseases depends on telomerase reactivation, and that an inhibiting agent of this enzyme could be an effective antitumor drug ${ }^{7,15}$.

Azidothymidine triphosphate (AZT) was shown in vitro to inhibit the action of telomerase in several tumour, with an important reduction of the telomeric terminals ${ }^{10,16-19}$.

The present study evaluated the telomerase activity and cell proliferation in HS839.T melanoma cells submitted to the action of AZT.

\section{Methods}

\section{Cell lines and cultures}

This study was approved by the Research Ethics Committee of Federal University of Sao Paulo under number $156 / 07$.
An immortalized isolated melanoma cell line named HS 839.T, catalog \# CRL-7572, derived from skin with fibroblast morphology of a 42-year-old Caucasian female patient, was purchased from the American Type Culture Collection (ATCC, Manassas, VA, USA). The cells were kept in DMEM medium (Gibco, Grand Island, NY, USA), supplemented with 10\% of FBS (Gibco, Grand Island, NY, USA), 0.02ml L-glutamine (Sigma Aldrich, St Louis, MO, USA), 4.5g/L glucose (Merck, New Jersey, USA), and $1.5 \mathrm{~g} / \mathrm{L}$ sodium bicarbonate (Merck, New Jersey, USA), and placed in an incubator at $37^{\circ} \mathrm{C}$ with $5 \% \mathrm{CO}_{2}$.

\section{Treatment of cells}

After achieving 80\% flask confluence, the cells were trypsinized (0.01\%) (Sigma Aldrich, St Louis, MO, USA) and submitted to different AZT concentrations, with one control group without drug addition, followed by a group to which $50 \mu \mathrm{M}$, $100 \mu \mathrm{M}$ and $200 \mu \mathrm{M}$ were added for 24 and 48 hours, respectively. The experiments were carried out in triplicate.

\section{Cell viability}

\section{MTT solution}

In order to determine the metabolic activity and the degree of cell proliferation, $10^{4}$ cells/well were distributed onto 96-well microplates with $100 \mu \mathrm{L}$ of DMEM medium, with the same supplementation. The plates were kept at $37^{\circ} \mathrm{C}$ with $5 \% \mathrm{CO}_{2}$ for 24 hours. Then the medium was aspired and replaced by fresh supplemented DMEM medium, simultaneously adding AZT at the defined concentrations for 24 and 48 hours, respectively.

The cells were incubated again at $37^{\circ} \mathrm{C}$ for 24 and 48 hours, respectively, then $10 \mu \mathrm{l}$ of MTT solution $(5 \mathrm{mg} / \mathrm{ml})$ were added to each well, maintained for three hours, and then the medium was aspired and $100 \mu 1$ acidified isopropanol were added to each well for ten minutes, to dissolve the formazan crystals. Analysis was performed with an ELISA plate reader (Labsystem Multiskan EX, Helsinki, Finland) at a wavelength of $450 \mathrm{~nm}$, with a reference filter of $590 \mathrm{~nm}$, and the metabolic activity was obtained by using its percentage in relation to the control.

\section{Telomerase activity}

Cell preparation for telomerase analysis

Cell preparation, reaction mixtures, PCR amplification and telomerase enzymatic expression analysis were performed with the Telomerase PCR ELISA ${ }^{\circledR}$ kit (Roche, Mannheim, 
Germany) and the TRAPEZE ${ }^{\circledR}$ RT kit (Chemicon, Temecula, CA, USA), according to the manufacturers' instructions.

Cells were trypsinized and the pellet was washed with a PBS solution (Sigma Aldrich, St Louis, MO, USA) and resuspended in $200 \mu \mathrm{L}$ CHAPS Lysis Buffer. The same procedure was performed with the TRAPEZE ${ }^{\circledR}$ RT kit, the cells were kept on ice for 30 minutes and then stored in a freezer at $-80^{\circ} \mathrm{C}$.

\section{Telomerase PCR ELISA ${ }^{\circledR}$ kit}

The cell extracts were unfrozen and aliquots were analyzed by the immunoenzymatic method (hybridization and ELISA), using the Telomerase PCR ELISA ${ }^{\circledR}$ kit. The immunoabsorbance of the samples was measured with an ELISA plate reader (Labsystem Multiskan EX, Helsinki, Finland) at a450 nm wavelength, with a $690 \mathrm{~nm}$ reference filter. A sample was considered positive for telomerase enzymatic activity if its immunoabsorbance was higher than $0.2 \mathrm{~A}_{450} \mathrm{~nm}-\mathrm{A}_{690} \mathrm{~nm}$ units.

\section{TRAPEZE ${ }^{\circledR}$ RT kit}

\section{Preparation of reaction mixtures}

Aliquots of: $0.4 \mu \mathrm{L}$ Hot Start Taq Polymerase, $37.6 \mu \mathrm{L}$ $\mathrm{dH} 2 \mathrm{O}$ and $10-750 \mathrm{ng} / \mu \mathrm{L}$ cell extract were prepared with reagents supplied by the manufacturer (Chemicon, Temecula, CA, USA). The cell extracts were unfrozen and analyzed using the TRAPEZE ${ }^{\circledR}$ RT kit.

The reaction mixture was then placed in an Eppendorf tube and taken to the thermocycler (Corbett Research Rotor Gene 3000, Sidney, Australia) for extension and amplification by polymerase chain reaction (PCR). Once the reaction was completed, the telomerase enzymatic expression was analyzed using real-time PCR.

To perform these experiments, a curve was constructed with standard protein (Figure 1), using 99\% BSA (fraction V) (Sigma Aldrich, St Louis, MO, USA) and a protein assay kit (Biorad Laboratories, Hercules, CA, USA).

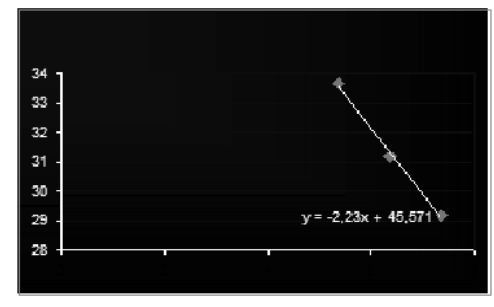

\begin{tabular}{lcc}
\hline \multicolumn{3}{l}{ Standard curve } \\
\hline TSR8 & Log & CT \\
20 & 7,38 & 29,2 \\
TSR8 & & \\
2 & 6,38 & 31,17 \\
TSR8 & & \\
0,2 & 5,38 & 33,66
\end{tabular}

FIGURE 1 - Standard curve: $X$ axis - $\log [10]$ concentration of the protein extract sample; Y axis - Threshold Cycle (CT) values of the dilution points; on the line, the marked CT values.

\section{Results}

\section{Cell viability}

\section{MTT solution}

The results obtained for the enzymatic activity values in the cells of the 24-hours' treatment group are presented in Figure 2. A gradual increase of the cell population was observed in all groups during the 24-hour period compared to the control group, with a tendency towards a decrease in enzymatic activity when $200 \mu \mathrm{M}$ of AZT were added.

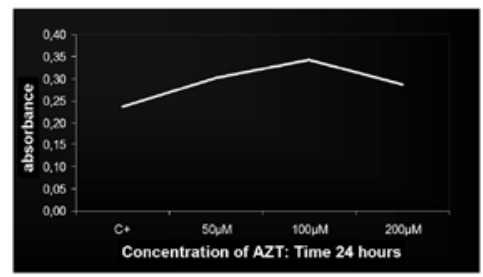

FIGURE 2 - Treatment for 24 hours: positive control and AZT concentrations in $\mu \mathrm{M}$, detection of cell viability by MTT, cell line HS839.T.

The results obtained for the enzymatic activity values in the cells of the 48-hours' treatment group are presented in Figure 3. A gradual increase of the cell population was observed in all groups during the 48-hour period compared to the control group, with no tendency towards a decrease in enzymatic activity when $200 \mu \mathrm{M}$ of AZT were added.

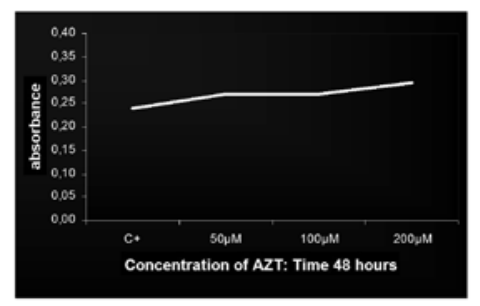

FIGURE 3 - Treatment for 48 hours: positive control and AZT concentrations in $\mu \mathrm{M}$, detection of cell viability by MTT, cell line HS839.T.

\section{Telomerase activity}

\section{Telomerase PCR ELISA ${ }^{\circledR}$ kit}

Telomerase activity was evaluated using the Telomerase PCR ELISA ${ }^{\circledR}$ kit in the control group and in the groups treated with AZT. The distribution of the immunoabsorbance values (OD) is shown in Figure 4. A gradual increase in telomerase activity was observed in all groups during the 24-hour period compared to the 
control group, with a tendency towards a decrease in enzymatic activity when $200 \mu \mathrm{M}$ of AZT were added.

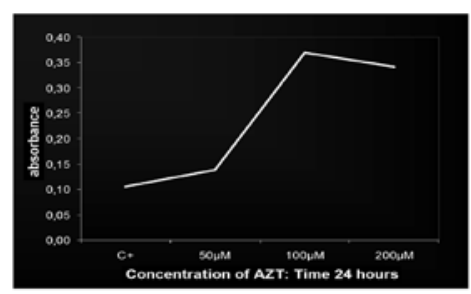

FIGURE 4 - Treatment for 24 hours: positive control and AZT concentrations in $\mu \mathrm{M}$, detection of specific telomerase activity in an HS839.T cell line by PCR-ELISA ${ }^{\circledR}$.

Telomerase activity was evaluated with the Telomerase PCR-ELISA kit, both in the control and in the groups treated with AZT. The distribution of the immunoabsorbance (OD) values concerning telomerase activity is presented in Figure 5. An initial decrease in telomerase activity was observed in the groups to which $50 \mu \mathrm{M}$ and $100 \mu \mathrm{M}$ of AZT had been added, after which there was a gradual increase compared to the control group, and no tendency towards a decrease in enzymatic activity was found with $200 \mu \mathrm{M}$ of AZT.

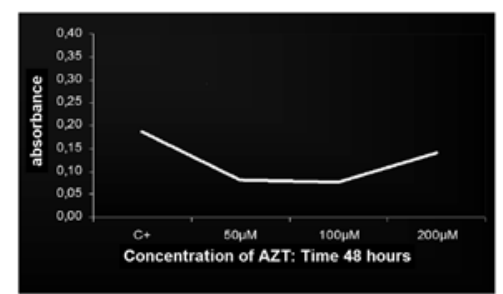

FIGURE 5 - Treatment for 48 hours: positive control and AZT concentrations in $\mu \mathrm{M}$, detection of specific telomerase activity in an HS839.T cell line by PCR-ELISA ${ }^{\circledR}$.

\section{TRAPEZE ${ }^{\circledR}$ RT kit}

Real-time polymerase chain reaction (RT-PCR) was performed using a TRAPEZE ${ }^{\circledR}$ RT kit, both in the control and in the groups treated with AZT (Figures 6 and 7). A gradual increase in telomerase enzymatic activity was observed in all groups treated for 24 hours compared to the control group, and a tendency towards a decrease in enzymatic activity was found with $200 \mu \mathrm{M}$ of AZT.

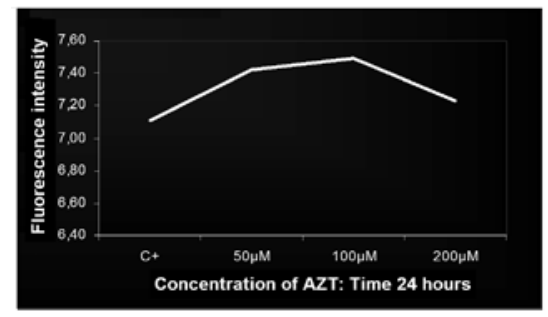

FIGURE 6 - Treatment for 24 hours: positive control and AZT concentrations in $\mu \mathrm{M}$, specific detection of telomerase activity in an HS839.T cell line by TRAPEZE RT ${ }^{\circledR}$.

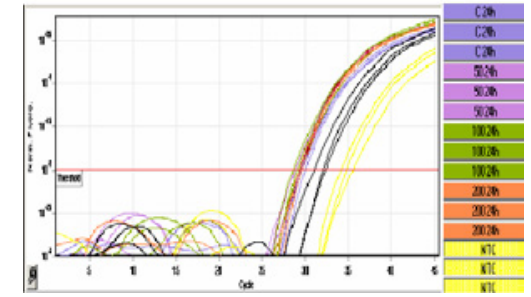

FIGURE 7 - Quantification of 24-hour samples, number of cycles: fluorescence monitoring curve illustrating real-time amplification.

RT-PCR was performed using a TRAPEZE ${ }^{\circledR}$ RT kit, both in the control and in the groups treated with AZT (Figures 8 and 9).

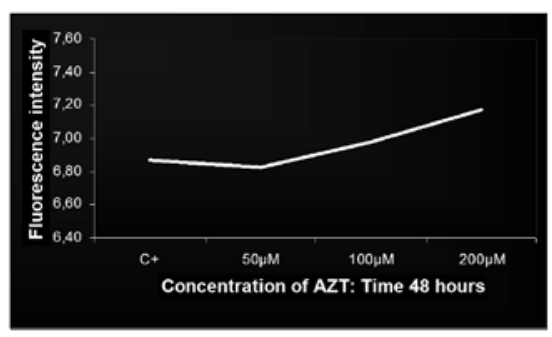

FIGURE 8 - Treatment for 48 hours: positive control and AZT concentrations in $\mu \mathrm{M}$, specific detection of telomerase activity in an HS839.T cell line by TRAPEZE RT ${ }^{\circledR}$.

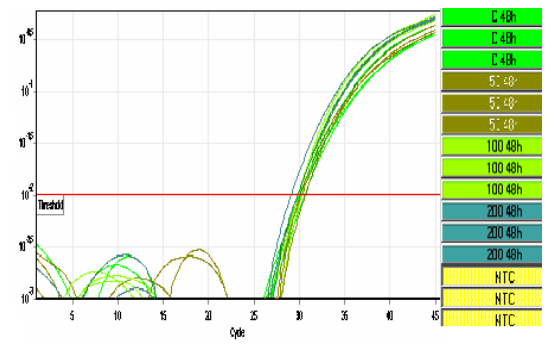

FIGURE 9 - Quantification of 48-hour samples, number of cycles: fluorescence monitoring curve illustrating real-time amplification.

A gradual increase in telomerase enzymatic activity was observed in all groups treated for 48 hours compared to the control group, and no tendency towards a decrease in enzymatic activity was found with $200 \mu \mathrm{M}$ of AZT.

To analyze the data resulting from this combination of distinct methodologies, we chose triangulation. The use of different data collection methods and the comparison of the results, i. e., the convergence or corroboration of the information gathered and interpreted concerning the same phenomenon, considering that validity and reliability are measures of consistency ${ }^{20}$. The data resulting from the experiments were compared and correlated with each other, in order to point out patterns, themes and concepts ${ }^{21}$, thus organizing basic descriptive units and interpretations involving the attribution of a meaning to the analyses, explaining the patterns found and searching for relationships among the descriptive dimensions. 
The primary theoretical reference in this study was qualitative, due to the fact that the sample was typically small, since we were looking for a cell behavior in front of a single bias, the different concentrations of $\mathrm{AZT}^{22}$.

\section{Discussion}

Melanoma develops from a malignant transformation of melanocytes, which undergo an uncontrolled growth and alterations in the nucleus ${ }^{20,21}$.

There is strong evidence indicating an association between the maintenance of telomeres and the development of most of the various types of cancer in humans, including melanoma ${ }^{22}$.

Telomerase functions as a reverse transcriptase and its inhibiting agents are being tested, among them azidothymidine triphosphate, zidovudine (AZT), and it has been proven that in vitro this drug inhibits the action of telomerase $\mathrm{e}^{10,16,17-19,23}$.

The objective of the present study was to evaluate the activity of telomerase and the proliferation of immortalized HS839.T melanoma cells submitted to the action of AZT, using MTT, the Telomerase PCR Elisa Kit and the telomerase Trapeze RT Kit.

For this purpose, we chose the melanoma cell line HS 839.T, in which this enzyme is active, because the behavior of this cell line is predictable and homogeneous.

To analyze the data resulting from this combination of distinct methodologies, we chose triangulation. The use of different data collection methods and the comparison of the results, i. e., the convergence or corroboration of the information gathered and interpreted concerning the same phenomenon, considering that validity and reliability are measures of consistency ${ }^{24}$. The data resulting from the experiments were compared and correlated with each other, in order to point out patterns, themes and concepts ${ }^{25}$, thus organizing basic descriptive units and interpretations involving the attribution of a meaning to the analyses, explaining the patterns found and searching for relationships among the descriptive dimensions.

The primary theoretical reference in this study was qualitative, due to the fact that the sample was typically small, since we were looking for a cell behavior in front of a single bias, the different concentrations of $\mathrm{AZT}^{26}$.

The evaluation of cell viability was performed according to the MTT technique ${ }^{27}$.

The AZT concentrations used were those most frequently mentioned in the literature ${ }^{10,16-18}$, and we added them directly to the culture medium, respecting the 24 and 48-hours' time of action.
All the experiments were carried out in triplicate because this is the ideal in vitro study design, once cells of the same cell line carry the same genetic material, ruling out any other bias.

The tests showed a gradual increase of the cell population in all groups treated with AZT for 24 hours compared to the control groups, with a tendency to decrease at the $200 \mu \mathrm{M}$ concentration. In the 48-hour groups, the same pattern was observed, but without the tendency to decrease at the dosage of $200 \mu \mathrm{M}$.

Telomerase activity was evaluated in the cell groups treated with AZT for 24 and 48 hours and in the control groups, using the Telomerase PCR Elisa Kit, according to a previously described methodology?

Telomerase activity was also measured using the commercial Trapeze ${ }^{\circledR}$ RT kit, because it allows real-time detection of the enzyme telomerase after fragment amplification in a thermocycler.

The results obtained with the 24-hours' treatment suggest that none of the different AZT concentrations $(50 \mu \mathrm{M}, 100 \mu \mathrm{M}$, and $200 \mu \mathrm{M}$ ) inhibited the telomerase activity as compared to the control group, although they suggest a tendency to a decrease with $200 \mu \mathrm{M}$.

Analyzing the results of the 48-hours' treatment, the same pattern was found, with an indication of a slight decrease in telomerase activity at the concentration of $50 \mu \mathrm{M}$ compared to the control group, although it was followed by a gradual increase in the activity of this enzyme, possibly related to the fact that the concentrations should have been higher, as suggested by Humer et al. ${ }^{28}$. Actually, our data corroborate the findings of Humer et $a .^{28}$, who studied growth inhibition of melanoma cells in vivo and in vitro and observed that AZT concentrations below $200 \mu \mathrm{M}$ did not produce measurable cytotoxic effects on the cells, but with higher concentrations up to $500 \mu \mathrm{M}$ and a longer exposure time up to 72hours, the tested cells showed a substantial increase in apoptosis, indicating a dose-dependent relationship. These data suggest that the HS839.T melanoma cells used in the present study are sensitive to AZT, but regain their enzymatic and proliferation activity, with a possible neutralization of the reverse transcriptase inhibiting nucleoside originated from AZT.

In conclusion, the action of AZT in HS839.T melanoma cells at the concentrations and time periods tested did not inhibit telomerase activity, nor did it affect cell proliferation. However, based on our results and on the findings of Humer et al. ${ }^{28}$, we will conduct further experiments, performed with melanoma cells obtained by fine-needle aspiration puncture (FNAP), submitted to AZT treatment starting from $200 \mu \mathrm{M}$ and with increasing doses and exposure of these cells to the drug for a period of time longer 
than 48 hours.

\section{References}

1. Santos IDAO, Brunstein F, Minami E, Carvalho C, Filho EFA, Ferreira LM. Neoplasias malignas de pele: análise epidemiológica de 1.242 pacientes operados. JBM. 1996;71(2):61-3.

2. Oliveira Filho RS, Paiva GR, Ferreira LM, Alves MCA, Santos IDAO, Enokihara MMSS. Linfonodo sentinela em melanoma em criança: Relato de caso. J Pediatr. 2002;78(5):429-32.

3. Oliveira AF, Gragnani A, Oliveira Filho RS, Santos IDAO, França SG, Enokihara MMSS, Ferreira LM. Modelo experimental de cultura primária de melanoma metastático por punção aspirativa de agulha fina. Acta Cir Bras. 2005;20(5):390-403.

4. Dhomen N, Reis-Filho JS, Dias SR, Hayward R, Savage K, Delmas V, Larue L, Pritchard C, Marais R. Oncogenic Braf induces melanocyte senescence and melanoma in mice. Cancer Cell. 2009;15:294-03.

5. Kashani-Sabet M, Rangel J, Torabian S, Nosrati M, Simko J, Jablons DM, Moore DH, Haqq C, Miller JR 3rd, Sagebiel RW. A multimarker assay to distinguish malignant melanomas from benign nevi. Proc Natl Acad Sci USA. 2009;106(15):6268-72.

6. McCormark D, Al-Shaer M, Goldschmidt BS, Dale PS, Henry C, Papageorgio C, Bhattacharyya K, Viator JA. Photoacoustic detection of melanoma micrometastasis in sentinel lymph nodes. J Biomech Eng. 2009;131(7):074519.

7. Carvalho L, Lipay M, Belfort F, Santos IDAO, Andrade J, Haddad A, Brustein F, Ferreita L. Telomerase activity in prognostic histopathologic features of melanoma. J Plast Reconstr Aesthet Surg. 2006;59(9):961-8.

8. Lejeune FJ, Ruegg C. Recombinant human tumor necrosis factor: an efficient agent for cancer treatment. Bull Cancer. 2006;93(8):90100.

9. Schultz J, Ibrahim SM, Vera J, Kunz M. 14-3-3 sigma gene silencing during melanoma progression and its role cycle control and cellular senescence. Mol Cancer. 2009;8(1):53.

10. Blackburn EH, Strahl C. Effects of reverse transcriptase inhibitors on telomere length and telomerase activity in two immortalized human cell lines. Mol Cell Biol. 1996;16(1):53-65.

11. Carrol KA, Ly H. Telomere dysfunction in human diseases: the long and short of it! Int J Clin Exp Pathol. 2009;2:528-43.

12. Piatyszek MA, Kim NW, Weinrich SL, Hiyama K, Hiyama E, Wright WE, Shay JW. Detection of telomerase activity in human cells and tumors by a telomeric repeat amplification protocol (TRAP). Methods Cell Sci. 1995;17:1-15.

13. Blackburn EH. Telomerase and cancer. Mol Cancer Res. 2005;3(9):477-82.

14. Souza Sobrinho CP, Gragnani A, Santos IDAO, Oliveira AF, Garcia JE, Ferreira LM. Cutaneous melanoma and telomerase. Appl Cancer Res. 2009;29(2):58-64.

15. Samalecos A, Reimann K, Wittmann S, Schulte HM, Brosens JJ, Bammerger, AM, Gellersen B. Characterization of a novel telomerase-immortalized human endometrial stroma cell line, StTib. Reprod Biol Endocrinol. 2009;7:76.

16. Melana SM, Holland JF, Pogo BG. Inhibition of cell growth and telomerase activity of breast cancer cells in vitro by 3-Azido-3'Deoxythymidine. Clin Cancer Res. 1998;4(3):493-6.

17. Brown T, Sigurdson E, Rogatko A, Brocoli D. Telomerase inhibition using azidothymidine in the HT-29 colon cancer cell line. Ann Surg Oncol. 2003;10(8):910-5.

18. Falchetti A, Franchi A, Bordi C, Mavilia C, Mais L, Cioppi F, Recenti R, Picariello L, Marini F, Del Monte F, Ghinoi V, Martineti V, Tanini A, Brandi ML. Azidothymidine induces apoptosis and inhibits cell growth and telomerase activity of human parathyroid cancer cells in culture. J Bone Miner Res. 2005;20(3):410-8.

19. Guo XL, Ma NN, Zhou FG, Zhang L, Bu XX, Sun K, Song JR, Li R, Zhang BH, Wu MC, Wei LX. Up-regulation of hTERT expression by low-dose cisplatin contributes to chemotherapy resistance in human hepatocellular cancer cells. Oncol Rep. 2009;22(3):549-56.

20. Figueiredo LC, Cordeiro LN, Arruda AP, Carvalho MDF, Ribeiro EM. Coutinho HDN. Câncer de pele: estudo dos principais marcadores moleculares do melanoma cutâneo. Rev Bras Cancerol. 2003;49(3):179-83.

21. Lee JH, Park H, Chung H, Choi S, Kim Y, Yoo H, Kim TY, Hann HJ, Seong I, Kim J, Kang KG, Han IO, Oh ES. Syndecan-2 regulates the migratory potential of melanoma cells. J Biol Chem. 2009;284(40):27167-75.

22. Davies H, Bignell GR, Cox C, Stephens C, Edkins S, Clegg S, et al. Mutations of the BRAF gene in human cancer. Nature. 2002;417(6892):949-54.

23. Fang JL, Beland FA. Long-term exposure to zidovudine delays cell cycle progression, induces apoptosis, and decreases telomerase activity in human hepatocytes. Toxicol Sci. 2009;111(1):120-30.

24. Driessnack M, Sousa VD, Mendes IAC. Revisão dos desenhos de pesquisa relevantes para enfermagem. Parte 3. Métodos mistos e múltiplos. Rev Latinoam Enferm. 2007;5:179-82.

25. Bradley J. Methodological issues and practices in qualitative research. Library Quartely. 1993;63(4):431-49.

26. Morse J. Principles of mixed methods and multimethod research design. Thousand Paks: Sage Publication;2003.

27. Momota H, Nerio E, Holland EC. Perifosine inhibits multiple signaling pathways in glial progenitors and cooperates with temozolomide to arrest cell proliferation in gliomas in vivo. Cancer Res. 2005;65(16):7429-35.

28 Humer J, Ferko B, Waltenberg, Rapberger R, Pehamberger H, Muster T. Azidothymidine inhibts melanoma cell grownth in vitro and in vivo. Melanoma Res. 2008;18(5):314-21

\section{Correspondence:}

Alfredo Gragnani

Rua Napoleão de Barros, $715 / 4^{\circ}$ andar

04024-900 São Paulo - SP Brasil

Tel.: (55 11)5576-4118

gragnani.dcir@epm.br

alfredogf@ig.com.br

\section{Received: July 18, 2012}

Review: September 19, 2012

Accepted: October 22, 2012

Conflict of interest: none

Financial source: Sao Paulo Research Foundation (FAPESP- 2007/592250)

${ }^{1}$ Research performed at Laboratory of Plastic Surgery Division, Department of Surgery, Paulista School of Medicine, Sao Paulo Federal University (EPM-UNIFESP), Brazil. Part of Fellow Master degree thesis, Postgraduate Program in Plastic Surgery. Tutor: Alfredo Gragnani. 